\title{
First report of Sapajus cay naturally infected by Trypanosoma cruzi in San Pedro Department, Paraguay
}

\author{
Primeiro relato de infecção natural em Sapajus cay por Trypanosoma cruzi em \\ Departamento San Pedro, Paraguai \\ Nidia Acosta ${ }^{1 *}$; Jorge Miret ${ }^{1}$; Elsa López ${ }^{1}$; Alicia Schinini ${ }^{1}$

\begin{abstract}
${ }^{1}$ Departamento de Medicina Tropical, Instituto de Investigaciones en Ciencias de la Salud, Universidad Nacional de Asunción UNA, San Lorenzo, Paraguay
\end{abstract}

Received May 5, 2016

Accepted June 27, 2016

\begin{abstract}
To verify the occurrence of natural Trypanosoma cruzi infection in non-human primates from a rural endemic area of the east region of Paraguay, xenodiagnosis was performed in 35 animals belonging to two species. For genotyping and T. cruzi discrete typing unit (DTU) assignment, a combination of four markers was used, including amplification products of the small (18S) and large (24S $\alpha)$ subunits of ribosomal ribonucleic acid gene, the intergenic region of mini-exon gene and the heat shock protein $60 \mathrm{Eco}$-RV polymerase chain reaction-restriction fragment length polymorphism (HSP6O/EcoRV-PCR-RFLP). One specimen of Sapajus cay was found positive and infected by the DTU TcII. This result constitutes the first record of natural T. cruzi infection in a sylvatic monkey in Paraguay, harbouring a DTU associated with severe Chagas disease in humans.
\end{abstract}

Keywords: Trypanosoma cruzi, primates, Paraguay.

\section{Resumo}

Com o objetivo de verificar a infecção natural por Trypanosoma cruzi em primatas não-humanos de uma área endêmica rural da regiáo leste do Paraguai, foi realizado o xenodiagnóstico em 35 animais pertencentes a duas espécies. Para a genotipagem foi utilizada a unidade discreta de tipagem (UDT) do T. cruzi, em uma combinaçáo de quatro marcadores, incluindo amplificação de produtos de pequena (18S) e grande $(24 S \alpha)$ subunidades do gene do ácido ribonucleico ribossômico, da regiâo intergênica de miniéxon e do gene da proteína de choque térmico 60 (HSP60/ EcoRV-PCR-RFLP), pela reação em cadeia da Polimerase. Um espécime de Sapajus cay se mostrou positivo pelo UDT TcII. Este resultado constitui o primeiro relato da infecçáo natural pelo T. cruzi em um macaco silvestre no Paraguai, abrigando um UDT associado com a doença de Chagas grave em humanos.

Palavras-chave: Trypanosoma cruzi, primatas, Paraguai.

\section{Introduction}

Trypanosoma cruzi is the causal agent of Chagas disease, a neglected parasitic disease that is estimated to affect approximately six millions people living in 21 countries of the Americas. It is estimated that 60 to 80 million are under risk of infection in endemic areas (WHO, 2015).

The infection for this parasite is considered primarily a zoonosis. Several species of sylvatic mammals were found naturally infected with this parasite, including over 73 genera and members of nine orders (JANSEN et al., 2015). Despite this wide range of hosts, the epidemiological importance of T. cruzi reservoirs varies according to the geographic region, the biology and ecology of these mammals

*Corresponding author: Nidia Acosta. Departamento de Medicina Tropical, Instituto de Investigaciones en Ciencias de la Salud, Universidad Nacional de Asunción - UNA, Cecilio Báez Casi Gaspar Villamayor, Campus San Lorenzo, San Lorenzo, Paraguay. e-mail: nidacostag@gmail.com and their interaction with triatomine vectors and humans. Studies on T. cruzi mammal infected species that have been performed in Paraguay include that one of Canese (1978), which examining a total of 17 wild animals found two specimens of Didelphis azarae positive for Trypanosoma spp. The remaining animals consisting of two armadillo species Dasypus novemcinctus and Tolypeutes matacus were negative as were two specimens of the fox Cerdocyon thous. A further study (FUJITA et al., 1994) encompassing 112 domestic and 4 sylvatic animals, including opossum, yellow armadillos and long-nosed armadillo from San Pedro Department, revealed 24 domestic animals seropositive for T. cruzi, of which 16 were dogs. Yeo et al. (2005) analyzed 146 animals in the area of San Pedro and Central Chaco, between 2000 and 2005, from ten different species, including D. novemcinctus, Euphractus sexcinctus, T. matacus, Chaetophractus spp., Galea musteloides, Calomys laucha, 
Graomys griseoflavus, Monodelphis domestica, Didelphis albiventris and Conepatus chinga. Twenty three animals being positive, which were D. novemcinctus, E. sexcinctus, Chaetophractus spp. and $M$. domestica. Monkey species were not included in these surveys. In general, primates act as reservoirs of parasitic diseases very related to human. Thus, parasitological studies about these species provide important information for a better understanding of the epidemiology and risk for emergence of several antropozoonosis.

Trypanosoma cruzi shows a phenotypic and genotypic substantial heterogeneity. Currently and according to the last consensus T. cruzi is divided into six discrete typing units or DTUs (ZINGALES et al., 2012), referred as TcI, TcII (ex TcIIb), TcIII (ex TcIIc), TcIV (ex TcIIa), TcV (ex TcIId) and TcVI (ex TcIIe). Additionally, a seventh DTU was described associated with bats (MARCILI et al., 2009a). These DTUs circulate in transmission cycles occurring in domestic and sylvatic habitats. The domestic cycle involves humans, domestic or synanthropic mammals, and domiciliated triatomines, whereas the sylvatic cycle includes multiple sylvatic triatomine species and several species of wild mammals. These transmission cycles can occur separately or overlapped, with the potential risk of parasite introduction into the domestic environment from the sylvatic area. A better understanding of the eco-epidemiology of T. cruzi in a given area can help in the development of improved disease control and surveillance strategies. Previous studies have been performed in Paraguay about the characteristics of strains of the domestic cycle, isolated from patients and domiciliary triatomines (CHAPMAN et al., 1984; MIMORI et al., 1992; ACOSTA et al., 1995, 2001), but very little is known about strains circulating in the sylvatic environment and their interrelations with the domestic cycle. Earlier studies in the San Pedro Department reported $14.3 \%$ of human seroprevalence for Chagas disease (CANESE, 1978). Likewise, Triatoma infestans and T. sordida specimens were found infesting houses (SENEPA, 2014) and currently is under epidemiological surveillance. This study was carried out in order to verify the occurrence of natural T. cruzi infection in non-human primates from a rural endemic area of the east region of Paraguay.

\section{Materials and Methods}

Animals were captured between February and April 2008 in ten rural localities of San Pedro Department (Table 1). This region corresponds to tropical and subtropical grassland, savanna and shrubland ecoregion, according to Olson et al. (2001). It is formed by wide plains with topography of valleys and small hills. It has abundant vegetation, humid climate with an annual rainfall from 800 to $1000 \mathrm{~mm}$, relative humidity of $63 \%$ and $83 \%$ and an average temperature of $23^{\circ} \mathrm{C}$. Approximately $30 \%$ of the population from this area still lives in precarious dwellings built with walls of wattle and brick, adobe, palm trunk, soil floor and straw, palm or tin roof (CENSO PARAGUAY, 2014).

The study included specimens kept as pets in the houses, and free-living ones, captured alive with the help of local hunters in wooded zones located at more than 3 kilometers from the dwellings. The specimens were identified by sex and species (NERIS et al., 2002), conforming to the taxonomy of capuchins lately proposed, in which the genus Cebus split into two genera: Cebus for gracile capuchins from the Amazon and Sapajus for robust capuchins from the Atlantic Forest (ALFARO et al., 2011, 2012; WALLACE, 2015). Then they were examined in the capture site; the free-living ones were released after sample collection. Animal handling procedures were according to the Guidelines of the American Society of Mammalogists (SIKES \& GANNON, 2011). This work was performed within the project: "Study of Yellow Fever in primates of outbreak areas of the San Pedro and Central Departments of Paraguay". The authorization of the Secretariat of Environment of Paraguay (SEAM), Certificate DVS No. 02/08 and the approval of the Scientific and Ethical Committees of the Instituto de Investigaciones en Ciencias de la Salud, Universidad Nacional de Asunción were obtained (code P03/08).

Table 1. Species of non-human primates tested for infection by Trypanosoma cruzi in localities from San Pedro Department, Paraguay.

\begin{tabular}{|c|c|c|c|c|c|c|}
\hline Locality & Latitude & Longitude & Species & $\begin{array}{c}\text { Total } \\
\text { captured }\end{array}$ & Habitat & Positive \\
\hline Yrybu cua & 243'ㄹ, $27,50^{\prime \prime} \mathrm{S}$ & $56^{\circ} 05^{\prime} 16,73^{\prime \prime} \mathrm{W}$ & Sapajus cay & 1 & pet & 0 \\
\hline \multirow[t]{2}{*}{ Vy'a renda } & \multirow[t]{2}{*}{$24^{\circ} 29^{\prime} 11,52 ” S$} & \multirow[t]{2}{*}{$56^{\circ} 07^{\prime} 12,28^{\prime \prime} \mathrm{W}$} & Sapajus cay & 9 & $\begin{array}{c}\text { pet (1) } \\
\text { free-living (8) }\end{array}$ & 0 \\
\hline & & & Alouatta caraya & 1 & pet & 0 \\
\hline Guayaibi & $24^{\circ} 31^{\prime} 46,65^{\prime \prime} \mathrm{S}$ & 56०24’20,24”W & Sapajus cay & 1 & pet & 0 \\
\hline Arroyo guazú & $23^{\circ} 47^{\prime} 57,76^{\prime \prime} \mathrm{S}$ & 5606'47,49”W & Sapajus cay & 1 & pet & 0 \\
\hline Coronel Mongelós & $24^{\circ} 40^{\prime} 39,62 ” S$ & 56²6’39,12”W & Sapajus cay & 2 & pet & 0 \\
\hline Calle 8000 Bertoni & 24०39'49,89"S & $56^{\circ} 25^{\prime} 30,77^{\prime \prime} \mathrm{W}$ & Sapajus cay & 1 & pet & 0 \\
\hline $\begin{array}{c}\text { Compañía General } \\
\text { Cáceres }\end{array}$ & $24^{\circ} 32^{\prime} 42,39^{\prime \prime S}$ & $56^{\circ} 37^{\prime} 41,086^{\prime \prime} \mathrm{W}$ & Sapajus cay & 11 & free-living & 1 \\
\hline \multirow{2}{*}{ Colonia Friesland } & \multirow{2}{*}{$2403658,75 ” S$} & \multirow{2}{*}{$56^{\circ} 46^{\prime} 55,34^{\prime \prime} \mathrm{W}$} & Sapajus cay & 3 & pet & 0 \\
\hline & & & Alouatta caraya & 1 & pet & 0 \\
\hline Compañía Tuyango & $24^{\circ} 34^{\prime} 41,34 ” S$ & $56^{\circ} 38^{\prime} 8,49^{\prime \prime} \mathrm{W}$ & Sapajus cay & 1 & free-living & 0 \\
\hline Compañía San Fernando & $24^{\circ} 49^{\prime} 42,94 ” S$ & $56^{\circ} 46^{\prime} 7,80^{\prime \prime} \mathrm{W}$ & Sapajus cay & 3 & free-living & 0 \\
\hline Total captured & & & & 35 & & 1 \\
\hline
\end{tabular}


Infection with trypanosomes was determined by xenodiagnosis (SCHENONE, 1999) using 20 fourth to fifth instar nymphs of Triatoma infestans reared in laboratory and free of trypanosome infection. Bugs for xenodiagnosis were provided by the Insectary of the Medicine Tropical Department of the Instituto de Investigaciones en Ciencias de la Salud. The primates were anesthetized with ketamine (Holliday-Scott ${ }^{\circ}, 50-80 \mathrm{mg} / \mathrm{kg}$ ) by intramuscular via to be submitted to xenodiagnosis. After two weeks, the feces of the insects were examined by optical microscopy to verify the presence of flagellates. Controls were performed until 60 days after feeding. The positive insects were dissected and the intestinal content was cultured in LIT (liver infusion tryptose) medium, (CAMARGO, 1964), supplemented with $10 \%$ foetal calf serum and incubated at $28^{\circ} \mathrm{C}$. DNA extraction was performed from parasite pellets using a DNeasy kit (QIAGEN ${ }^{\mathrm{TM}}$ ) following the manufacturer instructions. For genotyping and DTU assignment, a combination of four markers were used, including amplification products of the small (18S) and large $(24 S \alpha)$ subunits of ribosomal ribonucleic acid (rRNA) gene, the intergenic region of mini-exon gene and the polymerase chain reaction-restriction fragment length polymorphism of the heat shock protein 60 gene (HSP60/EcoRV-PCR-RFLP) profiles, as previously reported (YEO et al., 2005; LEWIS et al., 2009) (see Table 2). Amplified products were separated by electrophoresis in agarose gels (Sigma Chemical Co., St Louis, Mo) with 0.5X TBE buffer, stained with ethidium bromide, and visualized under ultraviolet light. X10 Clone I (TcI), Esmeraldo-Cl3 (TcII), ARMA 13 (TcIII), CAN III (TcIV), SC43 (TcV) and CL Brener (TcVI) were used as reference strains.

\section{Results}

Thirty five animals were analyzed in total, twenty males and fifteen females. Thirty three animals showed characteristics of the genus Cebus, which according to the new division belonging to Sapajus cay (Azaras's capuchin) species and the remains two were Alouatta caraya (howler monkey) (Table 1). Twelve of them corresponded to pets and 23 were free-living specimens. One sylvatic $S$. cay male specimen from Compañía General Cáceres was positive for T. cruzi infection giving a $2.85 \%$ of overall infection. Genotyping techniques performed in the T. cruzi isolate gave profiles expected for DTU TcII, according to Yeo et al. (2005) and Lewis et al. (2009), with amplification products at $125 \mathrm{bp}$ for the $24 \mathrm{~S} \alpha \mathrm{rRNA}$ PCR, at $165 \mathrm{bp}$ for the variable domain of the $18 \mathrm{~S}$ rRNA gene, at $300 \mathrm{bp}$ for the non-transcribed spacer region of the mini-exon gene and one band at 462 bp for the PCR-RFLP analysis of the
HSP60 gene. Figure 1 shows the result of this last marker, which allows the discrimination between TcII and TcVI DTUs. .

\section{Discussion}

This study constitutes the first report of T. cruzi infection in a monkey from Paraguay. T. cruzi-like trypanosomes were early reported infecting Cebus apella by Carvalheiro \& Barretto (1966) in woodland from the São Paulo Estate, Brazil. Bar et al. (1999) found $3.8 \%$ of infection in this primate species in Corrientes, Argentine Chaco. Jansen et al. (2015) also described specimens of Cebus spp. with natural infection in distinct Brazilian ecotopes especially in the Amazon and Atlantic forest. Primates from other species have been also found infected with this parasite, including Leontopithecus rosalia, Leontopithecus chrysomelas, Saimiri sciureus, in different regions of Brazil (ZICCARDI \& LOURENÇO-DE-OLIVEIRA, 1997; FERNANDES et al., 1999; LISBOA et al., 2004, 2006; MONTEIRO et al., 2007; JANSEN et al., 2015); Macaca silenus, Varecia variegata variegata, Lemur catta in the United States, (PUNG et al., 1998; HALL et al., 2007) among others. Reported infection rates ranged from $4 \%$ to $88 \%$ and infections of T. cruzi combined with $T$. rangeli in the Brazilian Amazon rainforest were described (ZICCARDI \& LOURENÇO-DE-OLIVEIRA, 1997; SILVA et al., 2008; JANSEN et al., 2015).

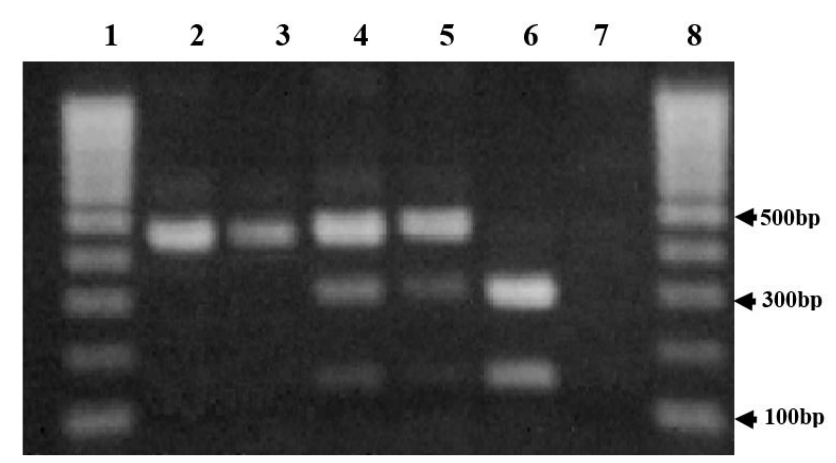

Figure 1. Agarose gel electrophoresis of PCR-RFLP products from HSP6O/EcoRV analysis of Trypanosoma cruzi isolates. Lanes: 1 and 8- molecular weight markers; 2- TcII reference strain Esmeraldo-Cl3 (462 bp); 3- Sapajus cay isolate (462 bp); 4- TcVI reference strain CL Brener (462/314/148 bp); 5- TcV reference strain SC43 (462/314/148 bp); 6- TcIII reference strain ARMA 13 (314/148 bp); 7- Negative control.

Table 2. Amplification products in base pairs (bp) of reference strains from different PCR reactions*.

\begin{tabular}{cccccccr}
\hline PCR reaction & TcI & TcII & TcIII & TcIV & TcV & TcVI & DTU \\
identification
\end{tabular}

* According to Yeo et al. (2005) and Lewis et al. (2009). ${ }^{* *}$ Allows the differentiation between TcII and TcVI DTUs. 
The two $A$. caraya of the present study were negative. However, species from the genus Alouatta were reported infected in Brazil (JANSEN et al., 2015) and in a recent survey in the northeastern of Argentina (MARTINEZ et al., 2016), therefore it is plausible that there are also positive specimens in this region of Paraguay.

C. apella is highly susceptible to T. cruzi infection and has been used as a model for experimental infections, being able to maintain parasitemia during long-term infection, with low level of severe symptoms that characterized Chagas disease in humans and without mortality (ALMEIDA et al., 1992; RIARTE et al., 1995). Long-lasting natural infection was also observed in L. rosalia (golden lion Tamarin) specimens, which after ten-year follow-up were able to maintain high parasitemias (LISBOA et al., 2015). This feature observed in primates can represent a risk factor for T. cruzi introduction and maintenance in the domestic environment, taking into account that they very often are kept as pets in this rural area of Paraguay, where T. infestans and T. sordida specimens were found infesting houses (SENEPA, 2014).

One positive specimen was found harbouring T. cruzi DTU TcII. This finding is interesting taking into account that this DTU was previously observed in a human case from San Pedro Department (ACOSTA et al., 2001) and that a different DTU (TcIII) was found circulating among sylvatic armadillos and in the marsupial $M$. domestica in the same area (YEO et al., 2005). In surveys performed in Brazilian Amazonia, several non-human primate species were reported infected with TcI and TcIV, the DTU TcI being the most common, associated with Rhodnius species (MARCILI et al., 2009b). In the Brazilian Atlantic forest, several monkey species were found infected with TcI and 'TcII' (without determination of TcII subgroup, according to the TcIla-e T. cruzi nomenclature at the time) separately and in mixed infections (LISBOA et al., 2006). Fernandes et al. (1999) also reported specimens of $L$. rosalia infected with 'TcII' (without determination of TcIla-e subgroup) in Rio de Janeiro state (Brazil). Recently, among captive Neotropical primates in a Brazilian zoo, TcI was reported associated with Panstrongylus species transmission (MINUZZI-SOUZA et al., 2016). T. cruzi isolates from lemurs in the United States were assigned to TcIV (HALL et al., 2007; ROELLIG \& YABSLEY, 2010) as well as isolates from wild primates in Bolivia and Venezuela (WESTENBERGER et al., 2006). TcII is found in the domestic area in Southern Cone countries, associated with severe Chagas disease in humans and its dynamics of transmission in sylvatic reservoirs is still poorly understood, despite that this DTU is considered ancestral (WESTENBERGER et al., 2005; FREITAS et al., 2006). Therefore, this study contributes with a new finding of DTU TcII infecting a sylvatic mammal in this zone. Further surveys are necessary to determine the transmission mechanism, maintenance and distribution of T. cruzi among these animals in this region.

Despite the low rate of infection observed in primates in this research, it expands our knowledge of the spectrum of wild reservoir species that could be infected by T. cruzi in a given area, especially when the same DTU that circulates in domestic area was found in the sylvatic monkey. Thus, primates from this region can constitute a source of parasites, being a potential threat for human health. This understanding should be taken into account when designing control measures against the parasite.

\section{Acknowledgements}

This study was financed by the Instituto de Investigaciones en Ciencias de la Salud, de la Universidad Nacional de Asunción (IICS-UNA). Especial thanks to Patricia Alcaráz, Mercedes Bogado and Cecilio Lezcano from the Primates Colony of the IICS-UNA, for their technical support. We thank the anonymous reviewers for their constructive comments. This paper is dedicated to Victoria Bogado (+).

\section{References}

Acosta N, Maldonado M, Sanabria L, Yaluff G, Fuentes S, Torres S, et al Characterization of Paraguayan Trypanosoma cruzi strains isolated from acute patients of Chagas disease. Trop Med Parasitol 1995; 46(3): $195-$ 200. PMid:8533024.

Acosta N, Samudio M, López E, Vargas F, Yaksic N, Brenière SF, et al. Isoenzyme profiles of Trypanosoma cruzi stocks from different areas of Paraguay. Mem Inst Oswaldo Cruz 2001; 96(4): 527-533. http://dx.doi. org/10.1590/S0074-02762001000400015. PMid:11391427.

Alfaro JW, Boubli JP, Olson LE, Di Fiore A, Wilson B, Gutiérrez-Espeleta GA, et al. Explosive Pleistocene range expansion leads to widespread Amazonian sympatry between robust and gracile capuchin monkey. J Biogeogr 2011; 39(2): 272-288. http://dx.doi.org/10.1111/j.13652699.2011.02609.x.

Alfaro JWL, Silva JS Jr, Rylands AB. How different are robust and gracile capuchin monkeys? An argument for the use of Sapajus and Cebus. Am J Primatol 2012; 74(4): 273-286. http://dx.doi.org/10.1002/ajp.22007. PMid:22328205.

Almeida EA, Navarro MR, Guariento ME, Carvalhal SS. The experimental infection of Cebus apella sp. monkeys with Trypanosoma cruzi. Its clinical, electrocardiographic and anatomicopathological assessment. Rev Soc Bras Med Trop 1992; 25(1): 7-12. http://dx.doi.org/10.1590/S003786821992000100002. PMid:1308068.

Bar ME, Alvarez BM, Oscherov EB, Damborsky M, Jörg ME. Contribution to knowledge of reservoirs of Trypanosoma cruzi (Chagas, 1909) in Corrientes Province, Argentina. Rev Soc Bras Med Trop 1999; 32(3): 271-276. http://dx.doi.org/10.1590/S0037-86821999000300008. PMid:10380566.

Camargo EP. Growth and differentiation in Trypanosoma cruzi I. Origen of metacyclic trypanosomes in liquid media. Rev Inst Med Trop Sao Paulo 1964; 6: 93-100. PMid:14177814.

Canese A. Datos actualizados sobre conocimientos epidemiológicos de la enfermedad de Chagas en el Paraguay. Rev Parag Microb 1978; 13(1): 7-19.

Carvalheiro JR, Barretto MP. Studies on wild reservoirs and vectors of Trypanosoma cruzi. 13. Natural infection of a monkey, Cebus apella versutus Elliot, 1910, by a T. cruzi-like trypanosome. Rev Bras Biol 1966; 26(2): 101-114. PMid:4969298.

Censo Paraguay. Dirección general de estadísticas, encuestas y censo [online]. 2014 [cited 2014 Jan 29]. Available from: http://www.dgeec.gov.py/

Chapman MD, Baggaley RC, Godfrey-Fausset PF, Malpas TJ, White G, Canese J, et al. Trypanosoma cruzi from the Paraguayan Chaco: isoenzyme profiles of strains isolated at Makthlawaiya. J Protozool 1984, 31(3): 482-486. http://dx.doi.org/10.1111/j.1550-7408.1984.tb02999.x. PMid:6239030. 
Fernandes O, Mangia RH, Lisboa CV, Pinho AP, Morel CM, Zingales $\mathrm{B}$, et al. The complexity of the sylvatic cycle of Trypanosoma cruzi in Rio de Janeiro state (Brazil) revealed by the non-transcribed spacer of the mini-exon gene. Parasitology 1999; 118(Pt2): 161-166. http://dx.doi. org/10.1017/S0031182098003709. PMid:10028530.

Freitas JM, Augusto-Pinto L, Pimenta JR, Bastos-Rodrigues L, Gonçalves VF, Teixeira SM, et al. Ancestral genomes, sex, and the population structure of Trypanosoma cruzi. PLoS Pathog 2006; 2(3): e24. http:// dx.doi.org/10.1371/journal.ppat.0020024. PMid:16609729.

Fujita O, Sanabria L, Inchaustti A, Arias AR, Tomizawa Y, Oku Y. Animal reservoirs for Trypanosoma cruzi infection in an endemic area in Paraguay. J Vet Med Sci 1994; 56(2): 305-308. http://dx.doi.org/10.1292/ jvms.56.305. PMid:8075219.

Hall CA, Polizzi C, Yabsley MJ, Norton TM. Trypanosoma cruzi prevalence and epidemiologic trends in lemurs on St. Catherines Island, Georgia. J Parasitol 2007; 93(1): 93-96. http://dx.doi.org/10.1645/GE-936R.1. PMid:17436947.

Jansen AM, Xavier SC, Roque AL. The multiple and complex and changeable scenarios of the Trypanosoma cruzi transmission cycle in the sylvatic environment. Acta Trop 2015; 151: 1-15. http://dx.doi. org/10.1016/j.actatropica.2015.07.018. PMid:26200785.

Lewis MD, Ma J, Yeo M, Carrasco HJ, Llewellyn MS, Miles MA. Genotyping of Trypanosoma cruzi: systematic selection of assays allowing rapid and accurate discrimination of all known lineages. Am J Trop Med Hyg 2009; 81(6): 1041-1049. http://dx.doi.org/10.4269/ajtmh.2009.09-0305. PMid:19996435.

Lisboa CV, Mangia RH, Rubião E, Lima NR, Xavier SC, Picinatti A, et al. Trypanosoma cruzi transmission in a captive primate unit, Rio de Janeiro, Brazil. Acta Trop 2004; 90(1): 97-106. http://dx.doi.org/10.1016/j. actatropica.2003.11.005. PMid:14739028.

Lisboa CV, Mangia RH, Luz SL, Kluczkovski A Jr, Ferreira LF, Ribeiro CT, et al. Stable infection of primates with Trypanosoma cruzi I and II. Parasitology 2006; 133(Pt5): 603-611. http://dx.doi.org/10.1017/ S0031182006000722. PMid:16836794.

Lisboa CV, Monteiro RV, Martins AF, Xavier SC, Lima VD, Jansen AM. Infection with Trypanosoma cruzi $\mathrm{T}$ cII and $\mathrm{TcI}$ in free-ranging population of lion tamarins (Leontopithecus spp): an 11-year follow-up. Mem Inst Oswaldo Cruz 2015; 110(3): 394-402. http://dx.doi.org/10.1590/007402760140400 . PMid:25946156.

Marcili A, Lima L, Cavazzana M, Junqueira AC, Veludo HH, Silva FM, et al. A new genotype of Trypanosoma cruzi associated with bats evidenced by phylogenetic analyses using SSU rDNA, cytochrome $b$ and Histone H2B genes and genotyping based on ITS1 rDNA. Parasitology 2009a; 136(6): 641-655. http://dx.doi.org/10.1017/S0031182009005861. PMid:19368741.

Marcili A, Valente VC, Valente SA, Junqueira AC, Silva FM, Pinto AY, et al. Trypanosoma cruzi in Brazilian Amazonia: Lineages TCI and TCIIa in wild primates, Rhodnius spp. and in humans with Chagas disease associated with oral transmission. Int J Parasitol 2009b; 39(5): 615-623. http://dx.doi.org/10.1016/j.ijpara.2008.09.015. PMid:19041313.

Martínez MF, Kowalewski MM, Salomón O, Schijman AG. Molecular characterization of trypanosomatid infections in wild howler monkeys (Alouatta caraya) in northeastern Argentina. Int J Parasitol Parasites Wildl 2016; 5(2): 198-206. http://dx.doi.org/10.1016/j.ijppaw.2016.05.001.

Mimori T, Maldonado M, Samudio M, Arias AR, Moreno R, Sakamoto M. Characterization of Trypanosoma cruzi isolates from Paraguay, using restriction enzyme analysis of kinetoplast DNA. Ann Trop Med Parasitol 1992; 86(3): 231-237. PMid:1333178.

Minuzzi-Souza TT, Nitz N, Knox MB, Reis F, Hagström L, Cuba $\mathrm{CA}$, et al. Vector-borne transmission of Trypanosoma cruzi among captive Neotropical primates in a Brazilian zoo. Parasit Vectors 2016; 9(1): 39. http://dx.doi.org/10.1186/s13071-016-1334-7. PMid:26813657.

Monteiro RV, Dietz JM, Raboy B, Beck B, Vleeschouwer K, Baker A, et al. Parasite community interactions: Trypanosoma cruzi and intestinal helminths infecting wild golden lion tamarins Leontopithecus rosalia and golden-headed lion tamarins L. chrysomelas (Callitrichidae, L., 1766). Parasitol Res 2007; 101(6): 1689-1698. http://dx.doi.org/10.1007/ s00436-007-0652-2. PMid:17676342.

Neris N, Colmán F, Ovelar E, Sukigara N, Ishii N. Guía de mamíferos medianos y grandes del Paraguay. Distribución, tendencia poblacional y utilización. Asunción: Secretaría del Ambiente/Agencia de Cooperación Internacional para el Desarrollo; 2002.

Olson DM, Dinerstein E, Wikramanayake ED, Burgess ND, Powell GV, Underwood EC, et al. Terrestrial ecoregions of the world: a new map of life on earth. Biosci 2001; 51(11): 933-938. http://dx.doi.org/10.1641/00063568(2001)051[0933:TEOTWA]2.0.CO;2.

Pung OJ, Spratt J, Clark CG, Norton TM, Carter J. Trypanosoma cruzi infection of free-ranging lion-tailed macaques (Macaca silenus) and ringtailed lemurs (Lemur catta) on St. Catherine's Island, Georgia, USA. J Zoo Wildl Med 1998; 29(1): 25-30. PMid:9638621.

Riarte A, Sinagra A, Lauricella M, Bolomo N, Moreno M, Cossio P, et al. Chronic experimental infection by Trypanosoma cruzi in Cebus apella monkeys. Mem Inst Oswaldo Cruz 1995; 90(6): 733-740. http://dx.doi. org/10.1590/S0074-02761995000600014. PMid:8731369.

Roellig DM, Yabsley MJ. Infectivity, pathogenicity, and virulence of Trypanosoma cruzi isolates from sylvatic animals and vectors, and domestic dogs from the United States in ICR strain mice and SD strain rats. Am J Trop Med Hyg 2010; 83(3): 519-522. http://dx.doi.org/10.4269/ ajtmh.2010.09-0663. PMid:20810814.

Schenone H. Xenodiagnosis. Mem Inst Oswaldo Cruz 1999; 94(S1): 289-294.

Servicio Nacional de Erradicación del Paludismo - SENEPA. Memoria anual institucional [online]. 2014 [cited 2014 March 23]. Available from: http://www.mspbs.gov.py/senepa

Sikes RS, Gannon WL. Guidelines of the American Society of Mammalogists for the use of wild mammals in research. J Mammal 2011; 92(1): 235253. http://dx.doi.org/10.1644/10-MAMM-F-355.1.

Silva FM, Naiff RD, Marcili A, Gordo M, D’Affonseca JA No, Naiff MF, et al. Infection rates and genotypes of Trypanosoma rangeli and T. cruzi infecting free-ranging Saguinus bicolor (Callitrichidae), a critically endangered primate of the Amazon Rainforest. Acta Trop 2008; 107(2): 168-173. http://dx.doi.org/10.1016/j.actatropica.2008.05.015. PMid:18603222.

Wallace RB. "Sapajus cay": e.T136366A70612036. Cambridge: The IUCN Red List of Threatened Species; 2015.

Westenberger SJ, Barnabé C, Campbell DA, Sturm NR. Two hybridization events define the population structure of Trypanosoma cruzi. Genetics 2005; 171(2): 527-543. http://dx.doi.org/10.1534/genetics.104.038745. PMid:15998728.

Westenberger SJ, Sturm NR, Campbell DA. Trypanosoma cruzi 5 S rRNA arrays define five groups and indicate the geographic origins of an ancestor of the heterozygous hybrids. Int J Parasitol 2006; 36(3): 337-346. http:// dx.doi.org/10.1016/j.ijpara.2005.11.002. PMid:16443226. 
World Health Organization - WHO. Chagas disease in Latin America: an epidemiological update based on 2010 estimates. Wkly Epidemiol Rec 2015; 90(6): 33-43. PMid:25671846.

Yeo M, Acosta N, Llewellyn M, Sánchez H, Adamson S, Miles GA, et al. Origins of Chagas disease: Didelphis species are natural hosts of Trypanosoma cruzi I and armadillos hosts of Trypanosoma cruzi II, including hybrids. Int J Parasitol 2005; 35(2): 225-233. http://dx.doi.org/10.1016/j. ijpara.2004.10.024. PMid:15710443.
Ziccardi M, Lourenço-de-Oliveira R. The infection rates of trypanosomes in squirrel monkeys at two sites in the Brazilian Amazon. Mem Inst Oswaldo Cruz 1997; 92(4): 465-470. http://dx.doi.org/10.1590/S007402761997000400003. PMid:9361738.

Zingales B, Miles MA, Campbell DA, Tibayrenc M, Macedo AM, Teixeira MMG, et al. The revised Trypanosoma cruzi subspecific nomenclature: rationale, epidemiological relevance and research applications. Infect Genet Evol 2012; 12(2): 240-253. http://dx.doi.org/10.1016/j.meegid.2011.12.009. PMid:22226704. 